\title{
Rosai-Dorfman Disease Complicated by Autoimmune Hemolytic Anemia in a Child: A Case Report and Review of the Literature
}

\author{
Amer A. Lardhi Abdullah K. Al-Mutairi Mohammed H. Al-Qahtani
} Atheer K. Al-Mutairi

King Fahad Hospital of the University, Faculty of Medicine, Imam Abdulrahman bin Faisal University, AL-Khobar, Kingdom of Saudi Arabia

\section{Keywords}

Autoimmune hemolytic anemia - Rosai-Dorfman disease - Sinus histiocytosis - Massive lymphadenopathy $\cdot$ Herpes simplex virus

\section{Abstract}

Rosai-Dorfman disease is a rare histiocytic proliferative disorder that commonly presents with a massive lymphadenopathy and a variety of constitutional symptoms. Severe hemolytic anemia is an infrequent complication of this disease. Although the etiology of the condition is unknown, infectious agents including viruses have been implicated. We describe a 2-yearold female child who presented with fever, pallor, and generalized lymphadenopathy complicated by the development of autoimmune hemolytic anemia. A review of the literature of this condition is also provided. 


\section{Case Reports in Oncology}

\section{Case Report}

A previously healthy 2-year-old female toddler from Sudan was admitted to the pediatric ward with the chief complaints of fever, weight loss, fatigability, pallor, and generalized lymphadenopathy. The symptoms started 2 months before presentation. Upon admission, the patient looked unwell, irritable, pyretic, pale, and had tachycardia. Anthropometric measurements were within normal values for age and sex. Widespread lymph node enlargement was observed in the head and neck region, as well as the presence of bilateral axillary nodes, and inguinal nodes (Fig. 1). The liver was felt $4 \mathrm{~cm}$ and the spleen $9 \mathrm{~cm}$ below the costal margins. Laboratory tests revealed anemia with a hemoglobin of $4.7 \mathrm{~g} / \mathrm{dL}$, high reticulocyte count $19.3 \%$, red blood cells (RBC) $0.81 \times 10^{6} / \mu \mathrm{L}$, mean cell volume $130.8 \mathrm{fL}$, leukocyte count of $16.5 \times 10^{3} / \mu \mathrm{L}$ with $78 \%$ neutrophils, $8 \%$ lymphocytes, $7 \%$ eosinophils, and $7 \%$ basophils. The platelets were normal: $244 \times 10^{3} / \mu \mathrm{L}$. The peripheral blood smear showed marked red blood cell agglutination along with polychromatic and spherocytic cells and nucleated RBC, consistent with acute hemolysis. The direct antiglobulin test (Coombs) was strongly positive a finding suggestive of autoimmune hemolytic anemia. The blood chemistry revealed increased levels of lactate dehydrogenase $426 \mathrm{U} / \mathrm{L}$, low albumin levels $1.4 \mathrm{~g} / \mathrm{dL}$ with normal serum bilirubin and liver enzymes. The erythrocyte sedimentation rate was elevated to $50 \mathrm{~mm}$ by the end of first hour and the C-reactive protein was $10.6 \mathrm{mg} / \mathrm{dL}$. The microbiology screen was negative when the body fluids were tested. The serology test was unremarkable for Epstein-Barr virus, cytomegalovirus, human immunodeficiency virus, Brucella, and toxoplasma. Herpes simplex virus IgG and IgM tests were positive. The tuberculin skin test was negative. The chest and abdominal CT scan revealed perihilar lymphadenopathy, para-aortic lymphadenopathy, and hepatosplenomegaly. The bone marrow aspirate revealed reactive hypercellular bone marrow with Mott cells (active plasma cells) and abnormal histiocytes with a high hemophagocytic activity (Fig. 2). A lymph node biopsy from the anterior cervical group (Fig. 3) showed that the sinusoids were extended and filled with S100 and CD68-positive but CD1a-negative histiocytes with abundant cytoplasmic fat globules and exhibited emperipolesis (viable lymphocytes inside the cytoplasm of histiocytes). The histiocytes were surrounded predominantly by a lymphocytic and plasmocytic infiltrate with formation of Russell bodies (plasma cells with large inclusions containing immunoglobulins).

The patient received one unit of packed $\mathrm{RBC}$ which temporarily raised her hemoglobin level to $6.1 \mathrm{~g} / \mathrm{dL}$; however, with the ongoing hemolysis, the hemoglobin dropped to $3.8 \mathrm{~g} / \mathrm{dL}$. Treatment was then started with $2 \mathrm{mg} / \mathrm{kg} /$ day of prednisolone. The patient showed a rapid clinical and laboratory improvement. The fever subsided by the third day of steroid therapy, and the lymph nodes became softer to palpation toward the end of the first week of the treatment. The hemoglobin increased to $8.7 \mathrm{~g} / \mathrm{dL}$ and the level reached $11.3 \mathrm{~g} / \mathrm{dL}$ upon discharge. The steroid treatment was tapered, and it was discontinued 4 months after presentation. The patient achieved clinical and laboratory remission with no evidence of hemolysis and had a negative direct Combs test. 


\section{Case Reports in Oncology}

\begin{tabular}{l|l}
\hline Case Rep Oncol 2018;11:55-62 \\
\hline DOI: 10.1159/000485968 & $\begin{array}{l}\text { (C) 2018 The Author(s). Published by S. Karger AG, Basel } \\
\text { www.karger.com/cro }\end{array}$
\end{tabular}

Lardhi et al.: Rosai-Dorfman Disease Complicated by Autoimmune Hemolytic Anemia in a Child: A Case Report and Review of the Literature

\section{Discussion}

Rosai-Dorfman disease (RDD), also known as sinus histiocytosis with massive lymph adenopathy, is a rare, mostly benign histiocytic disorder $[1,2]$. It is characterized by the proliferation and accumulation of histiocytes in the lymph nodes, but can also involve extranodal sites $[3,4]$. Although this disorder was described, initially by Rosai and Dorfman in young Africans, the disease is reported worldwide, and no racial group is spared. The etiology of the disease remains uncertain. The presence of autoimmune antibodies during the disease activity along with the several reports confirming serological evidence of recent bacterial or viral infection mainly herpes viruses suggests a possible link with an immune deregulatory activity secondary to infection [5-7]. The serological evidence of recent herpes simplex infection, may suggest a possible correlation with the RDD in our patient.

Acute life-threatening autoimmune hemolytic anemia has been described in several reports [8-10]. However, only 4 pediatric patients [11-13], including our case, with significant acute autoimmune hemolytic anemia, have been identified (Table 1). All patients had lymphadenopathy and symptoms of anemia upon presentation, along with low hemoglobin, high reticulocytes, and a strong positive direct antiglobulin test. In addition to blood transfusion, management of RDD has ranged from only steroid treatment, as in our patient, to the use of chemotherapeutic agents in resistant cases. The disease outcome among patients appears to be similar. However, a 7-year-old boy from Nigeria had a disease course complicated by sickle-cell anemia, infections, and cardiac failure secondary to dilated cardiomyopathy (Table 1).

The value of this report lies in the association of autoimmune hemolytic anemia with RDD in the presence of serological evidence of a recent herpes simplex virus, which further supports the hypothesis of an altered immunological process triggered by a viral illness.

\section{Statement of Ethics}

The authors have no ethical conflicts to declare.

\section{Disclosure Statement}

The authors declare that there are no conflicts of interest regarding the publication of this paper.

\section{References}

1 Rosai J, Dorfman RF: Sinus histiocytosis with massive lymphadenopathy. Arch Pathol 1969;87:63-70. Foucar E, Rosai J, Dorfman RF: Sinus histiocytosis with massive lymphadenopathy. Arch Otolaryngol 1978;104:687-693.

3 Lauwers GY, Perez-Atayde A, Dorfman RF, et al: The digestive system manifestations of Rosai-Dorfman disease (sinus histiocytosis with massive lymphadenopathy): review of 11 cases. Hum Pathol 2000;31:380-385. 


\section{Case Reports in Oncology}

Lardhi et al.: Rosai-Dorfman Disease Complicated by Autoimmune Hemolytic Anemia in a Child: A Case Report and Review of the Literature

-4 Kruse AL, Gengler C, Grätz KW, et al: Extranodal manifestation of Rosai-Dorfman disease without involvement of lymph nodes. J Craniofac Surg 2010;21:1733-1736.

-5 Levine PH, Jahan N, Murari P, et al: Detection of human herpes virus 6 in tissues involved by sinus histiocytosis with massive lymphadenopathy (Rosai-Dorfman disease). J Infect Dis 1992;166:291-295.

6 Tsang WY, Yip TT, Chan JK: The Rosai-Dorfman disease histiocytes are not infected by Epstein-Barr virus. Histopathology 1994;25:88-90.

7 Mehraein Y, Wagner M, Remberger K, et al: Parvovirus B19 detected in Rosai-Dorfman disease in nodal and extranodal manifestations. J Clin Pathol 2006;59:1320-1326.

8 Sachdeva M, Abdulhaq H: A rare case of Rosai-Dorfman disease in an adult male associated with autoimmune hemolytic anemia. Mediterr J Hematol Infect Dis 2013;5.

-9 Foucar E, Rosai J, Dorfman R: Sinus histiocytosis with massive lymphadenopathy (Rosai-Dorfman disease): review of the entity. Semin Diagn Pathol 1990;7:19-73.

10 Grabczynska SA, Toh CT, Francis N, Costello C, Bunker CB: Rosai-Dorfman disease complicated by autoimmune haemolytic anaemia: case report and review of a multisystem disease with cutaneous infiltrates. Br J Dermatol 2001;145:323-326.

11 Kiran PS, Sowdi VP, Sherry SB, et al: Sinus histiocytosis with massive lymphadenopathy: complicated by autoimmune hemolytic anemia. Indian J Pediatr 2003;70:759-760.

12 Stebbing C, Walt JVD, Ramadan G, et al: Rosai-Dorfman disease: a previously unreported association with sickle cell disease. BMC Clin Pathol 2007;7:3. Shanbari SA, Alhazmi W, Aljehani L, et al: Rosai Dorfman disease with autoimmune hemolytic anemia. EC Paediatr 2017;3.5:422-425. 


\section{Case Reports in Oncology}

Lardhi et al.: Rosai-Dorfman Disease Complicated by Autoimmune Hemolytic Anemia in a Child: A Case Report and Review of the Literature
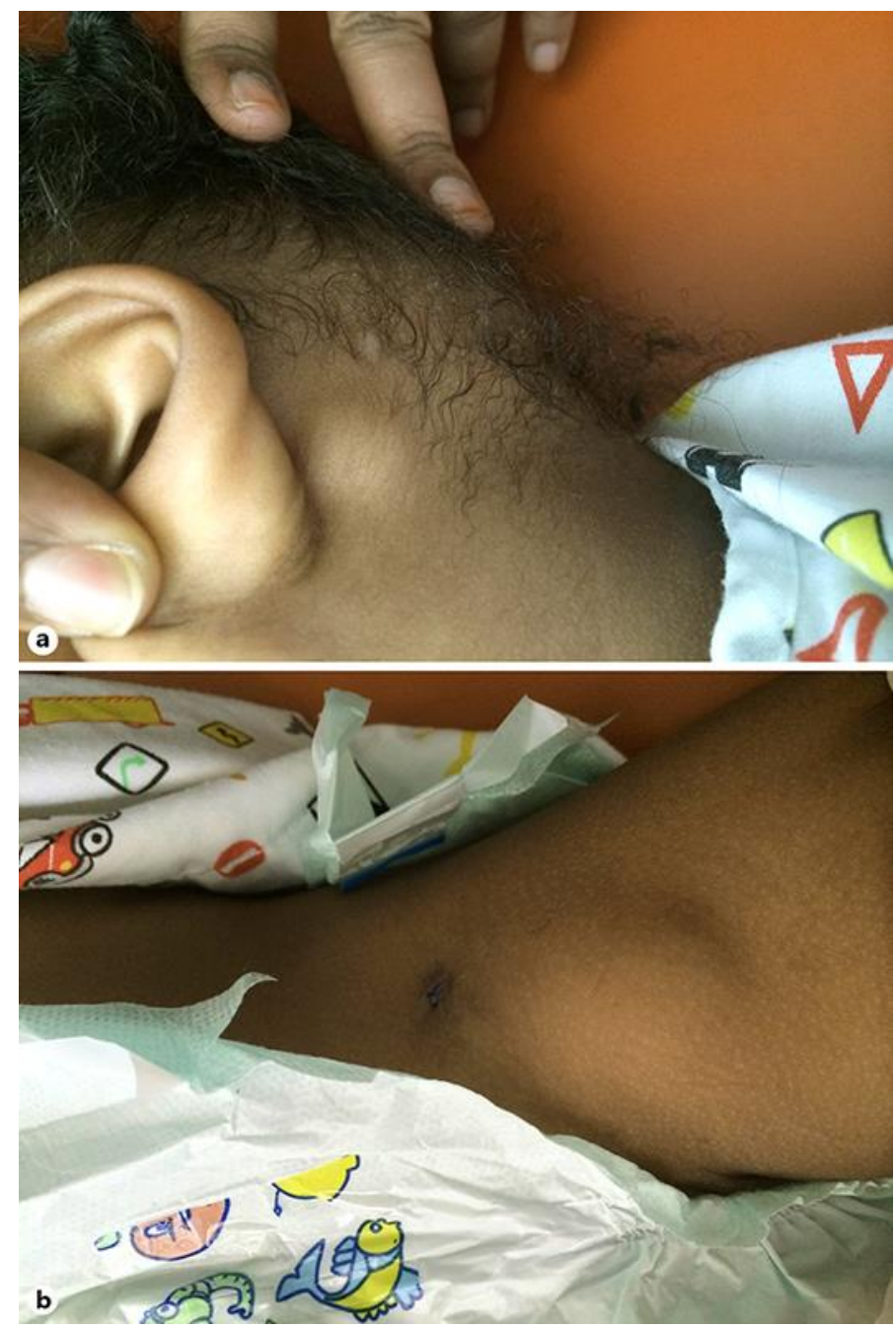

Fig. 1. Lymph node enlargement. a Postauricular. b Left inguinal. 


\section{Case Reports in Oncology}

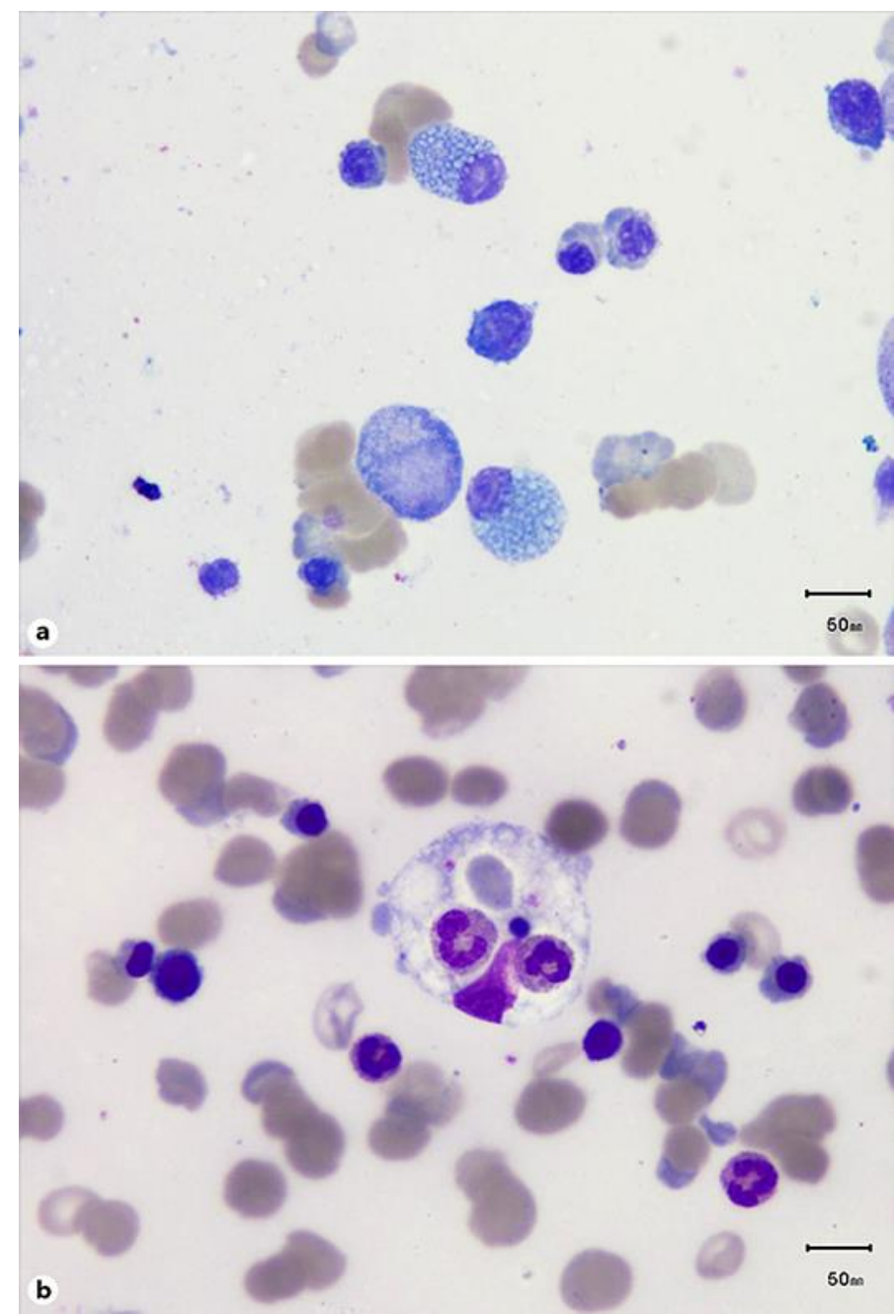

Fig. 2. Bone marrow aspirate showing plasma cells actively producing immunoglobulins "Mott cells" (a) and hemophagocytosis of RBC and neutrophils (b). 


\section{Case Reports in Oncology}


Fig. 3. Lymph node biopsy showing: large histiocytes with emperipolesis (black arrows) and plasma cells with large inclusions containing immunoglobulins "Russel body" (yellow arrow) (a); immunohistochemical staining of lymph node biopsy, positive for S100 (b); immunohistochemical staining of lymph node biopsy, positive for CD68 (c); immunohistochemical staining of lymph node biopsy, negative for CD1a (d); and immunohistochemical staining of lymph node biopsy, negative for CD21 (e). 


\section{Case Reports in Oncology}

\begin{tabular}{l|l}
\hline Case Rep Oncol 2018;11:55-62 \\
\hline DOI: $10.1159 / 000485968$ & $\begin{array}{l}\text { C } 2018 \text { The Author(s). Published by S. Karger AG, Basel } \\
\text { www.karger.com/cro }\end{array}$ \\
\hline
\end{tabular}

Lardhi et al.: Rosai-Dorfman Disease Complicated by Autoimmune Hemolytic Anemia in a Child: A Case Report and Review of the Literature

Table 1. Summary of clinical and laboratory findings in children with Rosai-Dorfman disease and anemia

\begin{tabular}{|c|c|c|c|c|c|c|}
\hline $\begin{array}{l}\text { Patient } \\
\text { [Ref.] }\end{array}$ & $\begin{array}{l}\text { Age/ } \\
\text { gender }\end{array}$ & Race & $\begin{array}{l}\text { Clinical } \\
\text { presentation }\end{array}$ & $\begin{array}{l}\text { Hgb level, } \\
\text { g/dL }\end{array}$ & Treatment & Outcome \\
\hline $1[7]$ & 10 years/M & $\begin{array}{l}\text { Black/ } \\
\text { Indian }\end{array}$ & LNP, HSM, pallor & 6.4 & $\begin{array}{l}\text { Vincristine, } \\
\text { cyclophosphamide, } \\
\text { prednisolone }\end{array}$ & $\begin{array}{l}\text { DCT negative, Hgb 10, HSM } \\
\text { regressed, responded } \\
\text { partially to chemotherapy }\end{array}$ \\
\hline $2[8]$ & 7 years $/ M$ & $\begin{array}{l}\text { Black/ } \\
\text { Nigerian }\end{array}$ & $\begin{array}{l}\text { SCD, intermittent } \\
\text { LNP, pallor }\end{array}$ & 2.6 & $\begin{array}{l}\text { Chronic blood } \\
\text { transfusion, } \\
\text { frequent admission } \\
\text { and antibiotics }\end{array}$ & $\begin{array}{l}\text { DCT remained positive, } \\
\text { infectious complications, } \\
\text { dilated cardiomyopathy }\end{array}$ \\
\hline 3 [9] & 18 months/M & $\begin{array}{l}\text { Black/ } \\
\text { Sudanese }\end{array}$ & $\begin{array}{l}\text { Fever, LNP, HSM, } \\
\text { pallor }\end{array}$ & 4.3 & Prednisolone & $\begin{array}{l}\text { DCT n.a., HSM regressed } \\
\text { responded partially, steroid } \\
\text { for } 1 \text { year }\end{array}$ \\
\hline $\begin{array}{l}4 \text { [this } \\
\text { report] }\end{array}$ & 2 years $/ F$ & $\begin{array}{l}\text { Black/ } \\
\text { Sudanese }\end{array}$ & $\begin{array}{l}\text { Fever, LNP, HSM, } \\
\text { pallor }\end{array}$ & 4.7 & $\begin{array}{l}\text { Prednisolone for } 4 \\
\text { months }\end{array}$ & $\begin{array}{l}\text { DCT negative, Hgb 11.3, HSM } \\
\text { regressed, responded well }\end{array}$ \\
\hline
\end{tabular}

Hgb, hemoglobin; SCD, sickle cell disease, LNP, lymphadenopathy; HSM, hepatosplenomegaly; DCT, direct Coombs test; n.a., not applied. 